\title{
Osteopathic postdoctoral education in transition
}

\author{
DOUGLAS WARD, PHD
}

HELEN H. BAKER, PHD

Because of alternative options for postdoctoral training made available by the AOA Board of Trustees and House of Delegates recently, this report summarizes the status of these important changes. The report also discusses the administration of postdoctoral education by the AOA and presents current statistics regarding internships, residencies, and certification.

\section{Administration of postdoctoral education in the AOA}

The Committee on Postdoctoral Training (COPT) was established by action of the AOA Board of Trustees in January, 1968, to assure the Bureau of Professional Education, the AOA Board of Trustees, the osteopathic medical profession, and the general public that postdoctoral programs were operating within approved standards, rules and regulations, and providing educational training satisfactory to the public interest. The COPT has 32 members from affiliate organizations representing the major branches of osteopathic medicine, hospital administration, the uniformed services, and directors of medical education. (See Appendix I, page 1403.)

The COPT works through the Division of Postdoctoral Training of the AOA Department of Education to regulate and monitor postdoctoral training in osteopathic institutions and evaluate postdoctoral training taken in the military and approved allopathic locations. This is done through inspections of training programs which are then reviewed by the Committee at its meetings in April and November each year.

The COPT is divided into two subcommittees. The intern subcommittee reviews all intern policies and procedures: new and existing intern programs; requests for increases in the number of positions at training sites; requests for approval of military internships; and any other matter pertinent to intern training. The residency subcommittee, working through the osteopathic specialty colleges, reviews all residency policies and procedures: all new and existing residency programs; requests for increase in the number of positions in training programs; requests for approval or recognition of allopathic and military specialty and subspecialty programs and training; and, any other issue pertinent to residency training.

Recommendations from the COPT on basic training documents and policy are defined by the $\mathrm{Bu}$ reau of Professional Education and the AOA Board of Trustees for approval, while routine program and training approval recommendations go directly to the Board of Trustees. Items which are recommended for denial by the COPT may be appealed to the Bureau of Professional Education prior to presentation to the Board of Trustees. The approval and appeal processes and other policies regarding postdoctoral training are published in the AOA's annual Yearbook and Directory of Osteopathic Physicians.

\section{Certification}

Specialty certification is awarded by the AOA Board of Trustees through the appropriate specialty boards and on recommendation from the Advisory Board for Osteopathic Specialists. The Advisory Board was established in 1939 by action of the AOA Board of Trustees to meet the needs resulting from the growth of specialization in the osteopathic medical profession. The Advisory Board is composed of one representative from each of the 18 specialty boards, two representatives from the Bureau of Professional Education, and a chairman and vice chairman appointed by the president of the AOA. In addition to making recommendations to the Board of Trustees concerning certification of physicians, the Advisory Board makes recommendations concerning the rules, regulations, and procedures established by the specialty boards. The Advisory Board is also charged with providing recommendations concerning the establishment of new certifying boards and the assignment or transfer of specialty and/or subspecialty jurisdiction.

\section{Osteopathic postdoctoral education}

Postdoctoral education in the osteopathic medical profession maintains that a well-trained physician must have a broad-based clinical education as a 
TABLE 1. INTERNSHIP - APPLICANTS AND POSITIONS, AS OF JULY 1 OF EACH YEAR.

\begin{tabular}{|c|c|c|c|}
\hline Intern class & 1986 & 1987 & 1988 \\
\hline $\begin{array}{l}\text { Number new graduates } \\
\text { Registrants who graduated in previous years }\end{array}$ & $\begin{array}{r}1,553 \\
11 \\
\end{array}$ & $\begin{array}{r}1,579 \\
12 \\
\end{array}$ & $\begin{array}{r}1,571 \\
30 \\
\end{array}$ \\
\hline Total available for internships & $\overline{1,564}$ & $\overline{1,591}$ & $\overline{1,601}$ \\
\hline $\begin{array}{l}\text { New graduates in funded osteopathic positions } \\
\text { New graduates in unfunded positions } \\
\text { New graduates in military programs } \\
\text { Subtotal for new graduates } \\
\text { Graduates from previous years in intern positions } \\
\text { DOs in allopathic programs, applied for "pilot program" }\end{array}$ & $\begin{array}{r}1,349 \\
6 \\
43 \\
1,398 \\
8 \\
\text { Not appl. }\end{array}$ & $\begin{array}{r}1,330 \\
3 \\
53 \\
1,386 \\
5 \\
47 \\
\end{array}$ & $\begin{array}{r}1,332 \\
0 \\
50 \\
1,382 \\
18 \\
31 \\
\end{array}$ \\
\hline Total in AOA-approvable internships & $\overline{1,406}$ & $\overline{1,438}$ & $\overline{1,431}$ \\
\hline $\begin{array}{l}\text { Applicants still seeking AOA positions } \\
\text { as of July } 1\end{array}$ & 9 & 21 & 22 \\
\hline \multicolumn{4}{|l|}{ Hospital positions } \\
\hline $\begin{array}{l}\text { Approved positions } \\
\text { Funded positions } \\
\text { Filled, funded positions } \\
\text { Filled, unfunded positions }\end{array}$ & $\begin{array}{r}1,643 \\
1,378 \\
1,357 \\
6 \\
\end{array}$ & $\begin{array}{r}1,660 \\
1,387 \\
1,330 \\
3 \\
\end{array}$ & $\begin{array}{r}1,774 \\
1,490 \\
1,350 \\
0 \\
\end{array}$ \\
\hline Subtotal, filled positions & $\overline{1,363}$ & $\overline{1,333}$ & $\overline{1,350}$ \\
\hline Vacant, funded positions & 21 & 37 & 140 \\
\hline
\end{tabular}

\begin{tabular}{|c|c|c|}
\hline & Number & $\%$ \\
\hline $\begin{array}{l}\text { Total commitments made between hospitals } \\
\text { and potential interns }\end{array}$ & 1,352 & \\
\hline $\begin{array}{l}\text { Agreements terminated by mutual consent: } \\
\text { Of these } 105,26 \text { interns }(25 \%) \text { went to } \\
\text { allopathic programs, and } 79(75 \%) \text { went } \\
\text { to other osteopathic programs }\end{array}$ & 105 & $7.8 \%$ \\
\hline $\begin{array}{l}\text { Breaching of contracts to go to allopathic } \\
\text { programs, release not obtained }\end{array}$ & 17 & $1.3 \%$ \\
\hline $\begin{array}{l}\text { Commitments broken by hospitals which closed } \\
\text { Of these } 15,14(93 \%) \text { went to other } \\
\text { AOA-approved programs }\end{array}$ & 15 & $1.1 \%$ \\
\hline Total releases in $1988-89$ & 137 & $10.2 \%$ \\
\hline
\end{tabular}

foundation for further postdoctoral education. As a result, the AOA internship is a required prerequisite for entrance into osteopathic residency programs. Participants in osteopathic internships must be graduates of AOA accredited colleges of osteopathic medicine.

The osteopathic internship has a core curriculum, including 12 weeks of internal medicine, 12 weeks of surgery, four weeks of general practice, four weeks of pediatrics, and four weeks of obstetrics and gynecology. Osteopathic principles and practices are integrated throughout the internship. This core curriculum is mandated regardless of future educational or practice choices, and is described in more detail in the AOA's annual Yearbook and Di- rectory of Osteopathic Physicians. Students interested in taking a military intern training program may apply for approval on an individual basis if the program rotations are equivalent to the rotating internship.

Following the internship, the AOA offers specialty and subspecialty residency programs which build on the internship year and give osteopathic physicians the opportunity to acquire advanced skills in specific specialty areas. Residency programs vary in length depending on the basic standards established by the specialty affiliate and approval by the AOA Board of Trustees. Currently there are 46 specialties with approved osteopathic residency programs which are designed to prepare the physician for examination for certification.

If an osteopathic physician who has completed an internship approved by the AOA is unable to obtain specialty or subspecialty training within the osteopathic profession, the resident may seek approval of the specialty training from the AOA. These policies and procedures are described in detail in the AOA's annual Yearbook and Directory of Osteopathic Physicians.

\section{Postdoctoral education in transitions}

During the past two decades, there have been tremendous increases in the number of graduates from osteopathic colleges. In 1970 , there were only 470 graduates from osteopathic colleges; by 1988 this number had more than tripled, to 1,570 . Conse- 


\begin{tabular}{|c|c|c|c|c|}
\hline Institution & $\begin{array}{l}\text { Approximate } \\
\text { date }\end{array}$ & $\begin{array}{l}\text { Intern } \\
\text { positions }\end{array}$ & $\begin{array}{l}\text { Residency } \\
\text { programs }\end{array}$ & $\begin{array}{c}\text { Residency } \\
\text { positions }\end{array}$ \\
\hline Saginaw Osteopathic Hospital, MI & March 1987 & 14 & 2 & 5 \\
\hline Baptist Medical Center, NY & November 1987 & 20 & 5 & 26 \\
\hline New Berlin Memorial Hospital, WI & April 1988 & 4 & 0 & 0 \\
\hline PCOM/St. Mary's Hospital/PA & June 1988 & 6 & 0 & 0 \\
\hline University Hospital/UHS, MO & July 1988 & $\underline{14}$ & $\underline{7}$ & $\underline{23}$ \\
\hline Total lost through closing & & $\overline{58}$ & $\overline{14}$ & $\overline{53}$ \\
\hline
\end{tabular}

quently, the profession was faced with unprecedented demand for postdoctoral positions. To meet this need, members of the profession and the AOA staff undertook the expansion of training opportunities in osteopathic hospitals, both by further development of existing programs and creation of new programs in osteopathic hospitals. Furthermore, in 1986, the Board of Trustees adopted a policy to encourage expansion of postdoctoral programs in colleges of osteopathic medicine's, intern and residency programs. These efforts toward expansion have led to substantial gains: there were 1,775 approved intern positions in 1988, compared to only 1,218 approved positions in 1982 (a $46 \%$ increase). There are 114 more approved intern positions in 1988 than one year before, and 149 additional residency positions.

The Board of Trustees also adopted a resolution which created a "pilot program" as a temporary option for students who were unable to obtain osteopathic positions. This program is available only to 1987,1988 , and 1989 graduates who actively participated in the Intern Registration Program but failed to find an osteopathic internship. If these graduates participate in an allopathic program which meets the rotation requirements of an AOAapproved internship, they may apply through a subcommittee of the COPT for individual approval of their internships. Subsequent Board action determined that this "pilot program" will terminate June 30,1990 , as adequate intern positions will be available within the profession by that time.

During the July 1988 meeting of the AOA House of Delegates and Board of Trustees, a resolution was adopted to support, in principle, the report of its Task Force on Alternate Approval Mechanisms for Postdoctoral Training. This resolution may have a major impact on postdoctoral education (see the September 1988 issue of THE DO). One proposal of the report is creation of alternate paths for approval of postdoctoral training for DOs who have completed an AOA-approved internship and have completed or will complete residency training not approved under existing AOA policies and procedures. Details of the procedures and implementation of

\begin{tabular}{|c|c|c|c|c|}
\hline & Approved & Funded & Filled & Vacant \\
\hline Arizona & 40 & 34 & 32 & 2 \\
\hline California & 56 & 40 & 36 & 4 \\
\hline Colorado & 19 & 15 & 14 & 1 \\
\hline Delaware & 6 & 6 & 2 & 4 \\
\hline Florida & 116 & 103 & 88 & 15 \\
\hline Georgia & 10 & 7 & 7 & 0 \\
\hline Illinois & 86 & 71 & 71 & 0 \\
\hline Indiana & 17 & 16 & 15 & 1 \\
\hline Iowa & 28 & 25 & 22 & 3 \\
\hline Kansas & 12 & 9 & 9 & 0 \\
\hline Maine & 19 & 19 & 19 & 0 \\
\hline Massachusetts & 4 & 2 & 2 & 0 \\
\hline Michigan & 308 & 268 & $25 \overline{3}$ & 15 \\
\hline Missouri & 86 & 66 & 62 & 4 \\
\hline New Jersey & 123 & 96 & 88 & 8 \\
\hline New Mexico & 6 & 6 & 4 & 2 \\
\hline New York & 180 & 138 & 110 & 28 \\
\hline Ohio & 189 & 166 & 146 & 20 \\
\hline Oklahoma & 76 & 60 & 58 & 2 \\
\hline Oregon & 7 & 5 & 5 & 0 \\
\hline Pennsylvania & 250 & 229 & 218 & 11 \\
\hline Rhode Island & 7 & 6 & 6 & 0 \\
\hline Texas & 81 & 64 & 55 & 9 \\
\hline Washington & 6 & 4 & 4 & 0 \\
\hline West Virginia & 27 & 27 & 19 & 8 \\
\hline Wisconsin & 15 & 8 & 5 & 3 \\
\hline Subtotal & $\overline{1,774}$ & $\overline{1,490}$ & $\overline{1,350}$ & 140 \\
\hline Military & - & - & 50 & - \\
\hline Total & & & 1,400 & \\
\hline
\end{tabular}

this proposal are under consideration by the appropriate AOA committees. We anticipate that the new mechanisms will begin to be approved in 198889 , with many of the alternatives in place by July 1989.

A second recommendation of the report is possible restructing of the internship. Institutions which choose to do so may continue their current rotating internship with little appreciable change. However, the proposed model would allow more flexibility in meeting the goal of preparing well-rounded general physicians while maintaining flexibility in meeting the needs of modern medical practice.

The proposed internship model decreases the number of required rotations; recommends additional emphasis on ambulatory, rather than hospitalbased, care; places additional emphasis on conti- 


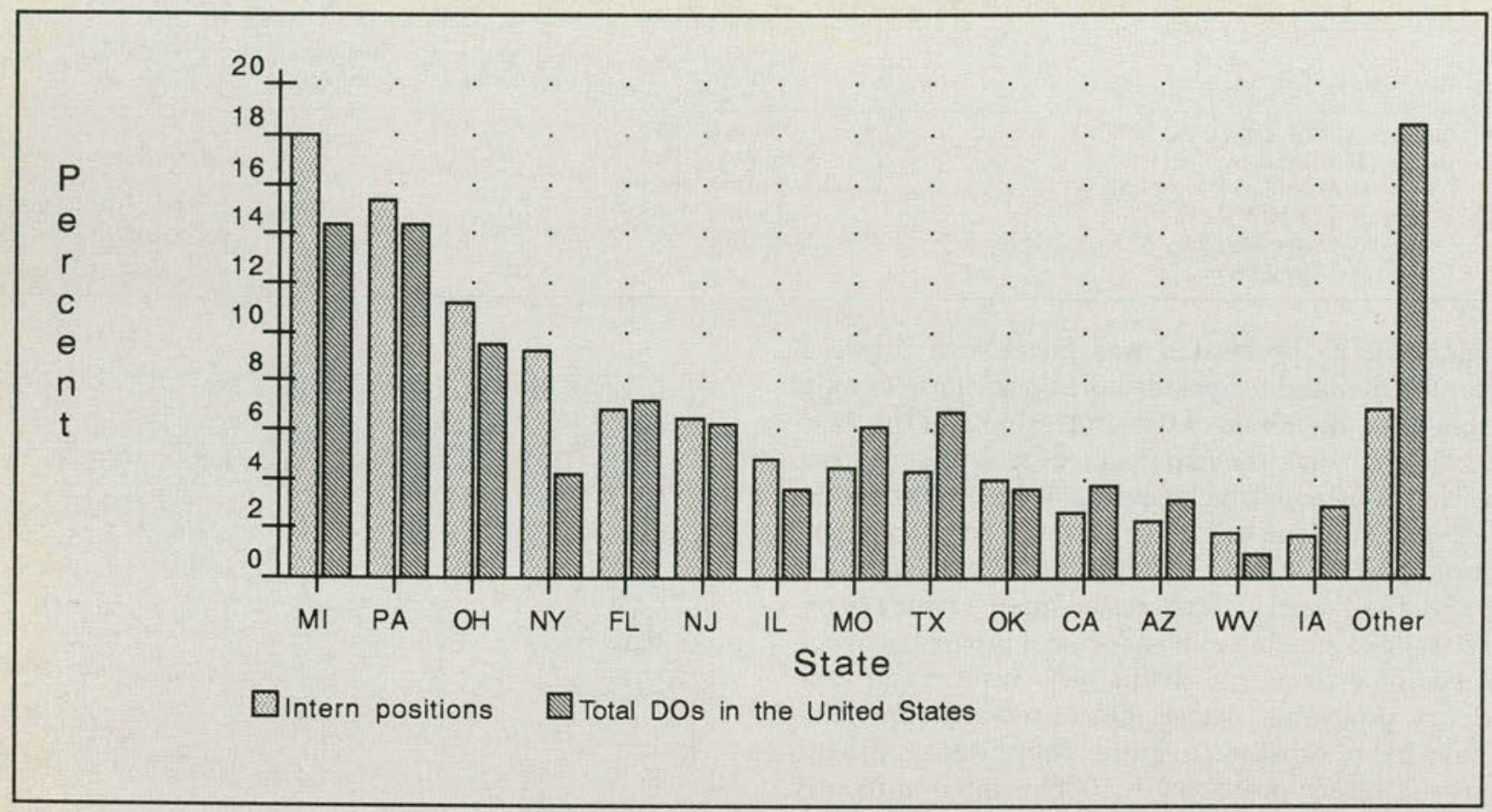

Fig 1. Intern positions and total DOs.

nuity of care; and adds flexibility for the director of medical education or program director to work with an intern to tailor the program to meet the intern's future needs. Specifically, the proposal recommends four months of general/internal medicine, one month of ambulatory gynecology, one month of general ambulatory pediatrics, one month of inpatient general surgery, two months of ambulatory surgical specialties, and three months of electives. It further recommends addition of a primary care component and a biopsychosocial component throughout the 12-month period. This model would allow reevaluation of the first year of residency training by appropriate specialty colleges, to more closely integrate the internship and residency programs. This proposal is now before the appropriate AOA committees and subcommittees for further input and development of implementation mechanisms.

The third recommendation of the task force report is even further expansion of postdoctoral training opportunities in osteopathic institutions. While substantial gains have been made in this area, further development is needed to improve both quality and quantity of postdoctoral education opportunities.

In yet another change, the intern registration program will, for the first time in 1988, use a com- puterized matching program. As before, interns and institutions are bound by the policies and procedures of the AOA, and may not make arrangements other than through this process. The deadline for receipt of materials from students and institutions is Jan 6,1989 , with results being reported on or about Feb 1.

Another major change approved by the Board in July 1988 was an increase in the general practice residency requirement, making it a two-year residency program. With inclusion of the intern year, this increase makes the general practice residency training sequence a three-year program.

\section{Osteopathic internships}

Table 1 summarizes results of the Intern Registration Program for the past three years. Note that the number of approved and funded intern positions increased from 1,387 in 1987 to 1,490 this year, an increase of 103 for the year. A total of 140 funded positions remained unfilled as of July $1,1988$.

Other than the increase in positions, the 1988 intern registration program results were similar to those from previous years. A total of $1,431 \mathrm{DOs}$ are in AOA-approvable internships; this represents $89.4 \%$ of the potential pool of applicants. This compares to $90.4 \%$ in 1987 and $89.4 \%$ in 1986 . 


\begin{tabular}{|c|c|c|c|c|c|c|c|c|c|}
\hline \multirow[b]{2}{*}{ Specialty } & \multicolumn{3}{|c|}{$1986-87$} & \multicolumn{3}{|c|}{$1987-88$} & \multicolumn{3}{|c|}{$1988-89$} \\
\hline & Pgms* & Pos $\dagger$ & Res $\ddagger$ & Pgms & Pos & Res & Pgms & Pos & Res \\
\hline Anesthesiology & 37 & 118 & 74 & 34 & 121 & 68 & 33 & 124 & 90 \\
\hline Dermatology & 1 & 2 & 0 & 2 & 4 & 0 & 2 & 4 & 5 \\
\hline Emergency Medicine & 17 & 70 & 50 & 17 & 83 & 76 & 16 & 123 & 85 \\
\hline General Practice & 60 & 326 & 200 & 69 & 388 & 243 & 72 & 452 & 318 \\
\hline Internal Medicine & 51 & 346 & 270 & 52 & 363 & 255 & 49 & 358 & 261 \\
\hline Allergy/Immunology & 0 & 0 & 0 & 0 & 0 & 0 & 0 & 0 & 0 \\
\hline Cardiology & 10 & 23 & 9 & 11 & 27 & 9 & 10 & 27 & 10 \\
\hline Endocrinology & 1 & 1 & 0 & 1 & 1 & 0 & 1 & 1 & 0 \\
\hline Gastroenterology & 6 & 16 & 8 & 6 & 16 & 7 & 6 & 16 & 9 \\
\hline Hematology & 2 & 6 & 0 & 2 & 6 & 1 & 2 & 6 & 2 \\
\hline Hematology/Oncology & 2 & 4 & 1 & 2 & 4 & 0 & 2 & 4 & 0 \\
\hline Infectious Diseases & 1 & 2 & 0 & 3 & 6 & 0 & 3 & 6 & 1 \\
\hline Medical Diseases of the Chest & 8 & 18 & 7 & 8 & 18 & 10 & 8 & 18 & 11 \\
\hline Nephrology & 4 & 10 & 0 & 4 & 10 & 2 & 4 & 10 & 0 \\
\hline Oncology & 0 & 0 & 0 & 0 & 0 & 0 & 0 & 0 & 0 \\
\hline Rheumatology & 1 & 1 & 0 & 1 & 1 & 0 & 1 & 1 & 0 \\
\hline Neurology & 5 & 13 & 9 & 5 & 13 & 6 & 5 & 13 & 12 \\
\hline Child Neurology & $\mathrm{n} / \mathrm{a}$ & $\mathrm{n} / \mathrm{a}$ & 0 & 0 & 0 & 0 & 0 & 0 & 0 \\
\hline Nuclear Medicine & 2 & 3 & 0 & 2 & 3 & 0 & 2 & 3 & 0 \\
\hline $\begin{array}{l}\text { Obstetrics and Gynecological } \\
\text { Surgery }\end{array}$ & 31 & 124 & 105 & 32 & 126 & 109 & 37 & 127 & 110 \\
\hline Ophthalmology & 15 & 40 & 27 & 16 & 42 & 29 & 15 & 41 & 30 \\
\hline Orthopedic Surgery & 34 & 125 & 112 & 33 & 130 & 116 & 34 & 138 & 120 \\
\hline Osteopathic Principles and Practices & 6 & 18 & 3 & 8 & 28 & 6 & 8 & 28 & 5 \\
\hline Otorhinolaryngology & 3 & 6 & 5 & 3 & 6 & 4 & 4 & 8 & 5 \\
\hline Oro-Facial Plastic Surgery & 16 & 49 & 33 & 16 & 50 & 31 & 16 & 51 & 36 \\
\hline Anatomic Pathology & 20 & 45 & 10 & 20 & 45 & 6 & 18 & 43 & 12 \\
\hline Pediatrics & 20 & 73 & 21 & 18 & 68 & 25 & 15 & 71 & 27 \\
\hline Neonatal Medicine & 1 & 2 & 0 & 2 & 6 & 0 & 2 & 6 & 0 \\
\hline Public Health/Preventive Medicine & 1 & 2 & 0 & 1 & 3 & 0 & 1 & 2 & 0 \\
\hline Proctology & 5 & 8 & 4 & 5 & 8 & 3 & 4 & 6 & 1 \\
\hline Psychiatry & 5 & 36 & 20 & 5 & 36 & 19 & 5 & 36 & 29 \\
\hline Child Psychiatry & 2 & 4 & 0 & 2 & 4 & 0 & 2 & 4 & 0 \\
\hline Radiology & 13 & 51 & 35 & 13 & 51 & 48 & 12 & 52 & 59 \\
\hline Angiography & 1 & 1 & 0 & 1 & 2 & 0 & 1 & 2 & 0 \\
\hline Neuroradiology & 1 & 1 & 1 & 1 & 1 & 0 & 1 & 1 & 0 \\
\hline Nuclear Radiology & 1 & 1 & 1 & 1 & 2 & 1 & 1 & 2 & 0 \\
\hline Radiation Oncology & 1 & 1 & 0 & 1 & 2 & 0 & 2 & 4 & 1 \\
\hline Diagnostic Ultrasound & 1 & 1 & 0 & 1 & 1 & 1 & 1 & 1 & 0 \\
\hline Diagnostic Radiology & 15 & 52 & 49 & 14 & 50 & 19 & 15 & 72 & 15 \\
\hline Rehabilitation Medicine & 2 & 5 & 3 & 2 & 6 & 3 & 2 & 6 & 3 \\
\hline \multicolumn{10}{|l|}{$\begin{array}{l}\text { Surgery } \\
\text { Surgane }\end{array}$} \\
\hline General & 51 & 215 & 188 & 54 & 223 & 168 & 53 & 223 & 196 \\
\hline General Vascular & 4 & 8 & 1 & 4 & 8 & 0 & 3 & 6 & 1 \\
\hline Neurological & 6 & 13 & 5 & 7 & 16 & 9 & 6 & 14 & 10 \\
\hline Plastic and Reconstructive & 0 & 0 & 0 & 0 & 0 & 0 & 0 & 0 & 0 \\
\hline Thoracic/Cardiovascular & 3 & 7 & 0 & 3 & 7 & 0 & 2 & 5 & 0 \\
\hline Urological & 16 & 35 & 17 & 15 & 33 & 16 & 14 & 31 & 16 \\
\hline Total & $\overline{482}$ & $\overline{1,882}$ & $\overline{1,268}$ & $\overline{497}$ & $\overline{2,018}$ & $\overline{1,290}$ & $\overline{490}$ & $\overline{2,146}$ & $\overline{1,480}$ \\
\hline $\begin{array}{l}* \text { Pgms }=\text { AOA approved residency progra } \\
\text { † Pos }=\text { approved positions. } \\
\ddagger \text { Res }=\text { residents in AOA approved osteop }\end{array}$ & trainin & grams. & & & & & & & \\
\hline
\end{tabular}

In 1988,22 new graduates $(1.4 \%)$ remain unmatched in any program. This number is consistent with previous years. Approximately 103 registrants took allopathic programs and 44 did not register with the AOA, bringing the total believed to be in allopathic programs to 147 , or $9.2 \%$.

Table 2 addresses concern for intern agreements which were not filled. As shown in the table, most of these were mutual releases, to allow an intern to take a position in another osteopathic program. 
Table 3 shows the loss of positions occurring because of hospital closings. These closings remain a source of great distress, in spite of the fact that the total number of available positions has been steadily increasing (Table 1 ). When a closing hospital has had interns or residents in training at the time of the closing, the Directors of Medical Education and the AOA have been able to assist with relocation of the trainees, and in every case where AOA assistance was sought, an AOA-approved position was identified for the resident or intern.

Table 4 lists intern positions and their geographic location. Ninety-two percent of the funded intern positions are found in the states with osteopathic colleges. Fig 1 shows, by state, a graph of intern positions and proportion of D.O.s. Six states account for $67 \%$ of the interns positions. Initiatives are under way to focus expansion of intern programs on "small states" and states for which there is unmet demand for intern positions.

\begin{tabular}{|lrr|r|}
\hline \multicolumn{3}{|l|}{ TABLE 6. PHYSICIANS RECEIVING CERTIFICATION, $1986-1988$, AS } \\
OF AUGUST 31, 1988. & & & \\
\hline & 86 & 87 & 88 \\
\hline & 0 & 0 & 0 \\
Allergy and Immunology & & & \\
Preventive Medicine/ & 4 & 1 & 2 \\
$\quad$ Aerospace Medicine & 3 & 19 & 14 \\
Anesthesiology & 0 & 3 & 2 \\
Anatomic Pathology & & & \\
Anatomic Pathology & 1 & 0 & 0 \\
and Laboratory Medicine & 22 & 13 & 8 \\
Cardiology & 0 & 1 & 0 \\
Child Neurology & 0 & 1 & 1 \\
Child Psychiatry & 7 & 3 & 7 \\
Dermatology & 21 & 16 & 25 \\
Diagnostic Radiology & 37 & 38 & 30 \\
Emergency Medicine & 2 & 1 & 2 \\
Endocrinology & 2 & 0 & 3 \\
Fellow of the AAO & 4 & 7 & 5 \\
Gastroenterology & 0 & 0 & 1 \\
Gynecologic Oncology & 247 & 285 & 384 \\
General Practice & 0 & 0 & 9 \\
General Vascular Surgery & 0 & 2 & 0 \\
Hematology & 0 & 0 & 0 \\
Hematology and Oncology & 1 & 1 & 2 \\
Infectious Disease & 59 & 78 & 80 \\
Internal Medicine & 1 & 2 & 1 \\
Laboratory Medicine & 6 & 7 & 7 \\
Medical Diseases of the Chest & 0 & 0 & 1 \\
Maternal and Fetal Medicine & 0 & 3 & 6 \\
Neurology & 4 & 1 & 1 \\
Neonatology & 3 & 4 & 4 \\
Nephrology & 3 & 0 & 1 \\
Nuclear Medicine & 3 & 0 & 0 \\
Neurological Surgery & 0 & 11 & 13 \\
Obstetrics and Gynecology & & \\
& & & \\
\hline
\end{tabular}

\section{Positions available-residencies}

Table 5 reports data on residency training programs and residents in training. These data include programs approved at the July 1988 AOA Board of Trustees meeting. In 1988, there are 128 more positions than in 1987, and 264 more positions than 1986. The number of residents in training in osteopathic programs in 1988 shows a $7 \%$ increase over 1987 and a $15 \%$ increase since 1986 .

\section{Certification}

Table 6 shows certification granted in 1986 through 1988. In 1980, a total of 276 physicians received certification; by 1988 , this number had more than doubled, to 714 .

Table 7 shows resident in nonosteopathic program who have received AOA approval of their training program.

\section{Summary}

Postdoctoral osteopathic education is in transition.

\begin{tabular}{|lrrr|}
\hline $\begin{array}{l}\text { Preventive Medicine/ } \\
\quad \text { Occupational Medicine/ } \\
\quad \text { Environmental Medicine }\end{array}$ & 13 & 5 & 6 \\
$\begin{array}{l}\text { Obstetric/Gynecological } \\
\quad \text { Surgery }\end{array}$ & 16 & 0 & 0 \\
$\begin{array}{l}\text { Preventive Medicine/ } \\
\quad \text { Occupational Medicine }\end{array}$ & 0 & 0 & 0 \\
Oncology & 4 & 4 & 2 \\
Otorhinolaryngology and & & & \\
$\quad$ Oro-Facial Plastic & & & \\
$\quad$ Surgery & 2 & 7 & 7 \\
Ophthalmology & 5 & 12 & 8 \\
Oro-Facial Plastic Surgery & 1 & 0 & 2 \\
Orthopedic Surgery & 15 & 20 & 21 \\
Otolaryngology & 0 & 0 & 0 \\
Otorhinolaryngology & 1 & 0 & 2 \\
Psychiatry & 0 & 8 & 8 \\
Pediatrics & 11 & 20 & 16 \\
Preventive Medicine & & & \\
$\quad$ and Public Health & 0 & 4 & 0 \\
Plastic and Reconstructive & & & \\
$\quad$ Surgery & 0 & 0 & 0 \\
Proctology & 0 & 2 & 1 \\
Radiology & 3 & 2 & 2 \\
Reproductive Endocrinology & 0 & 0 & 2 \\
Rheumatology & 0 & 0 & 1 \\
Rehabilitation Medicine & 5 & 4 & 6 \\
Radiation Oncology & 0 & 1 & 1 \\
Diagnostic Roentgenology & 0 & 0 & 0 \\
Surgery (General) & 15 & 17 & 9 \\
Thoracic/Cardiovascular & & & \\
$\quad$ Surgery & 4 & 4 & 5 \\
Radiation Therapy & 2 & 0 & 0 \\
Thoracic Surgery & 0 & 0 & 0 \\
Urological Surgery & 7 & 6 & 6 \\
$\quad$ Total Number of Physicians & & \\
$\quad$ Per Year & 534 & 613 & 714 \\
\hline
\end{tabular}




\section{For patients with elevated cholesterol}

\section{THS MAY BE THE \\ BETIER ANIIHYPERTENSIVE}

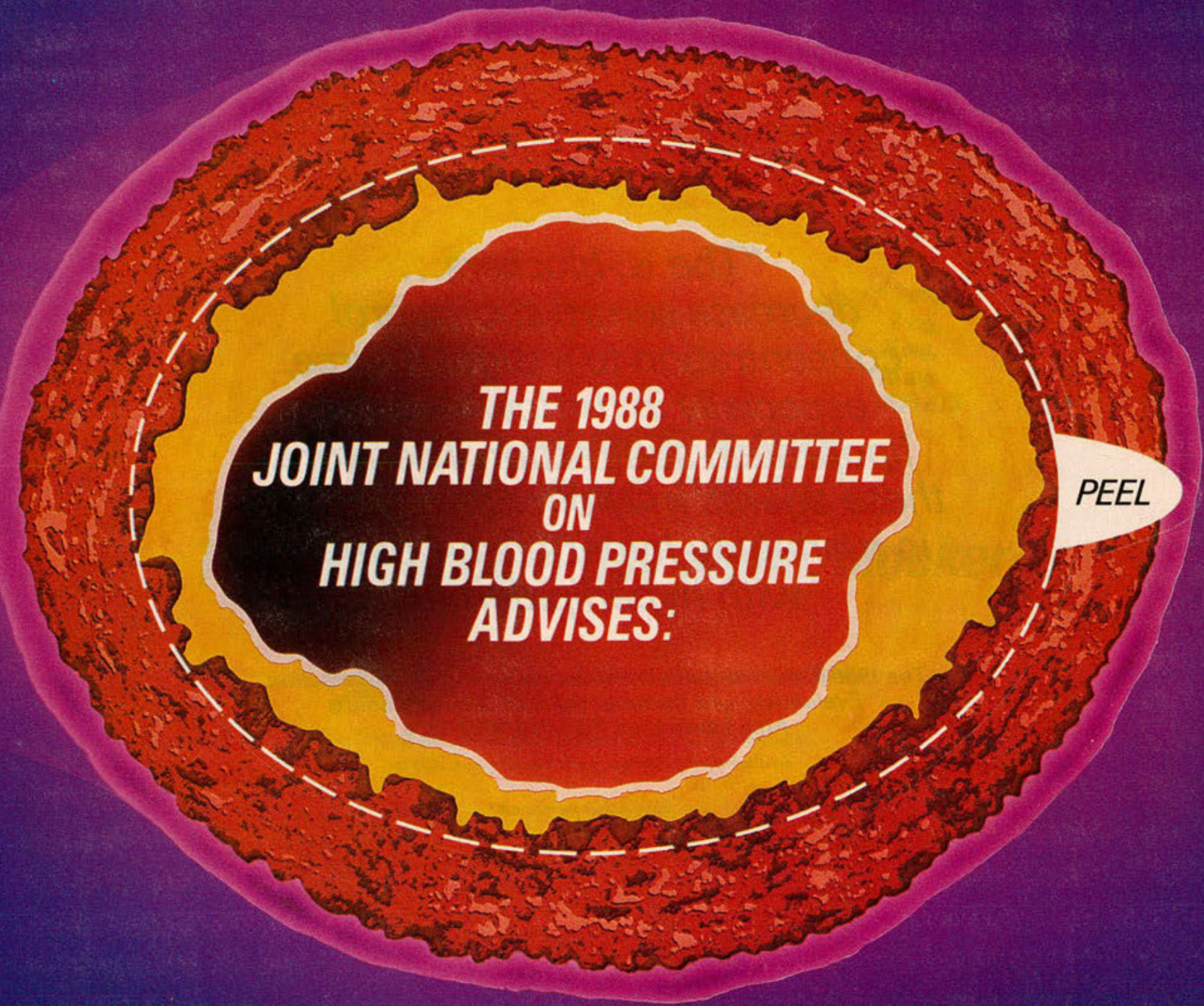




\section{Superior lipids performance in hypertensive patients with elevated cholesterol ${ }^{12 *}$}

\section{HDT

During controlled clinical studies, patients receiving HYTRIN had a small but significant decrease $(-3 \%)$ compared to placebo in total cholesterol and $L D L+V L D L$ cholesterol fraction.'
Although HDL fraction showed a slight increase from baseline and triglycerides decreased, neither change was significant compared to placebo.",

\begin{tabular}{|c|c|c|c|c|c|}
\hline & $\begin{array}{c}\text { Alpha, blockers } \\
(\text { HYTRIN })^{2.3}\end{array}$ & $\begin{array}{c}A C E \\
\text { inhibitors }{ }^{45}\end{array}$ & $\begin{array}{c}\text { Calcium } \\
\text { antagonists }^{45}\end{array}$ & Diuretics $^{3}$ & $\begin{array}{c}\text { Beta } \\
\text { blockers }^{3}\end{array}$ \\
\hline Total cholesterol & 1 & $\longleftrightarrow$ & $\longleftrightarrow$ & 1 & $\Longleftrightarrow$ \\
\hline$L D L+V L D L$ cholesterol & $\downarrow$ & $\longleftrightarrow$ & $\longleftrightarrow$ & $\uparrow$ & \\
\hline HDL cholesterol & $\longleftrightarrow$ 1 & $\Longleftrightarrow$ & $\Longleftrightarrow$ & $\Rightarrow$ & $\int$ \\
\hline Triglycerides & $\Leftrightarrow 1$ & $\Longleftrightarrow$ & $\Longleftrightarrow$ & & $\uparrow$ \\
\hline
\end{tabular}

-HYTRIN is not indicated for the treatment of hyperlipidemia

† Average wholesale price.

\section{HYTRIN}

(terazosin hydrochloride tablets)

Briet Summary

CLINICAL PHARMACOLOGY: Pharmacodynamics: Clinical studies of terazosin used in once-a-day (majority) and b.id regimens with total doses usually in the range of $5.20 \mathrm{mg} / \mathrm{day}$, in patients with mild or moderate hyperten sion.
first fecw doses, the initial dose was $1 \mathrm{mg}$ in vintually all studies, with subsequent titration to a specified fixed dose

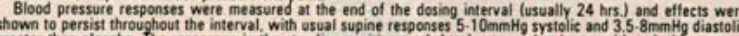

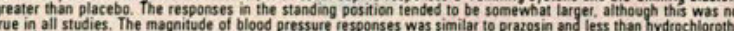
azide (in a single study). In measurements 24 hrs. after dosing, heart rate was unchanged.
Limited measurements of peak response $(2-3$ hrs. after dosing) during chronic terazofin administration indicate that it is more than twice the trough (24 hr.) response, sugpesting some attenuation of response at 24 hrs, pre

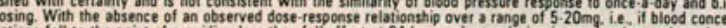
The latter should be considered if side effects. such as dizziness, papitations, or orthostatic complaints, are seen within a few hours after dosing.
The greater BP effect associated with peak plasma concentrations (first few hours after dosing) appears some The greater BP effect associated with peak plasma concentrations (first few hours after gosing) appears some
what more position. dependent (greater in the erect position) than the effect of terazosin at 24 hirs In the erect po-

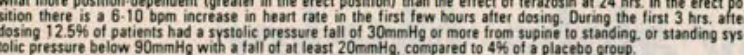
INDICATIONS AND USAGE, indicated for the treatment of hypertension:

INDICATIONS AND USAGE: Indicated
CONTRAINDICATIONS: None known.

WARNINGS: Syncope and "First-dose" Effect: Terazosin, like other alpha-adrenergic blocking agents, eas

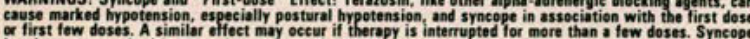
has been reported with other alpha-adrenergic blocking agents in association with rapid dosage increase of introduction of anothet antihypertensive drug. Syncepe may be due to an excessive posturaf hypottensive with heart rates of $120-160$ bpem. To decrease the likelihood of syncope or excessive hypotension, always initiate treatment with a $1 \mathrm{~m}$ siowiry, could result if syneope occurs during initiation of therapy. Caution patients to avoid situations where In early studies. where incteasing single doses up to $7.5 \mathrm{mg}$. were given at 3 day intervals tolerance to the first sose phenomenon did not necessarily develop and the - - first dose- etfect was observed at all doses. Syncopal ept

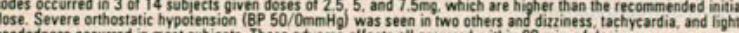
headedness occurred in most subjects. These adverse effects all occurred within 90 min. of dosing
In multiple dose clinical trials involving nearty 2000 patients, syncope was reported in 2000 t $1 \%$ of patients, nose severe or prolonged, and was not necessarily associated with earty doses.
it If syncope occurs. place patient in recumbent position and treat supportively. There is evidence that the

While syocope is the most severe onthostatic effect of

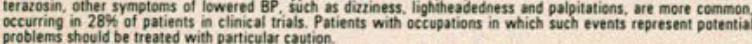
Information for Patients. Make aware of possibility of syncopal and orthostatic symptoms, especially at initiation fter interruption of theraey when treatment is resumed. Caution to avoid situations where inger could its

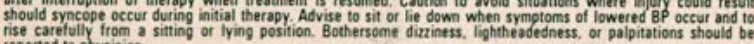
Tell patients that drowsiness or somnolence can octur, requiring caution in people who must drive or operale heavy machinery.

Laboratory Tests: Small but statistically significant decieases in hematocrit, hemoglobin. WBC, total grotein an albumin were observed in clinical trials. The magnitude of decreases did not worsen with time. These tindings sug. Orug Interactions; In controlled trials, terazosin was added to diuretics, and several beta-adrenergic blockers: $n$ 50 patients on the following 1 ) analgesic/anti-inflammatory (acetaminophen. aspirin. codeine. buprofen, indo

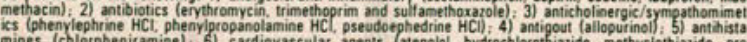

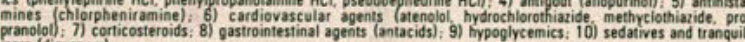

Carcinogenesis, Mutagenesis, Impairment of Fertility: HYTRIN was devoid of mutagenic potential when evaluated
in wivo and in vitro
HYTRIN statistically significant increase in benign adrenal medullary tumors of male rats exposed to the $250 \mathrm{mg} / \mathrm{kg}$ dose.
This dose is $695 \mathrm{X}$ max. recommended human dose (20mg/55kg). Female rats were unaffected. HYYRTI was not

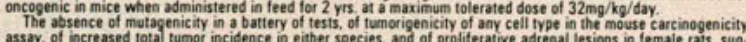
assay, of increased lotai fumor incidence in either species, and of proliferative adrenal lesions in female rals, sup.

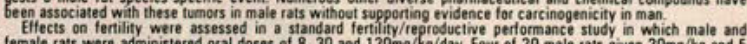
t 19 mats wert a smears at 30 and $120 \mathrm{mg} / \mathrm{kg} /$ day appeared to contain less sperm than smears from control matings and good corre Oral use for 1 or 2 yra. elicited a statistically significant increase in testicular atrophy in rats exposed to 40 and

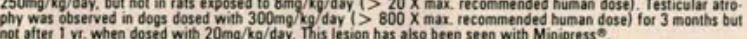

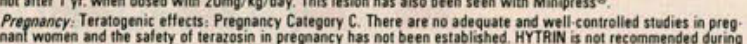
pregnancy unless potential benefit justifies potential risk to mothet and fetus. Nonteratogenic effects in a perit and post-natal development study in rats, significantly more pups died in the
group dosed with $120 \mathrm{mg} / \mathrm{kg} / / \mathrm{day} />300 \mathrm{X}$ max. recommended human dose) than in the control group during the Nursing Mothers: it is not known whether terazosin is excreted in breast milk; therefore, exercise caution when odministering terazosin to a nursing woman.

Pediatric Use : Safety and effectiveness have not been determined.

ADVERSE REACTIONS: The prevalence of adverse reactions has been ascertained from 14 placebo-controlled studies conducted primarily in the U.S. The studies involved once-a-day administration of terazosin as monotherapy or in combination with other antihypentensive agents, at doses ranging from 1 to $40 \mathrm{mg}$. All adverse events reported roup was at least $5 \%$, where the prevalence rate for the terazosin group was at least $2 \%$ and was greater than he prevalence rate for the placebo group, of where the reaction is of particular intertst are summarized below.
Only asthenia, blurred vision, dizziness, nasal congestion, nausea, peripheral edema, palpitations and somnolence

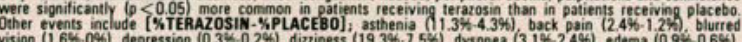

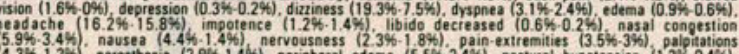

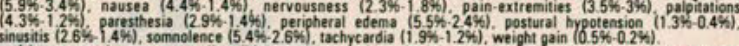

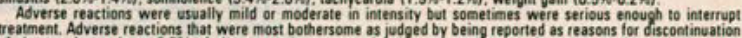

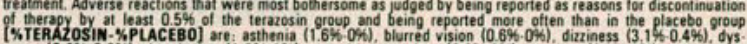

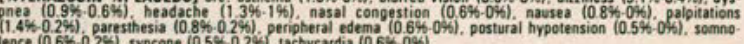

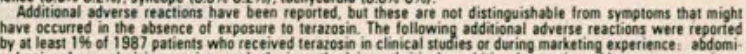

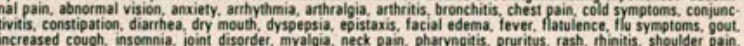

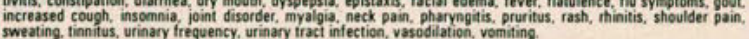
DOSAGE AND ADMINISTRATION: Dose and dose interval ( 12 or $24 \mathrm{hrs}$ ) should be adjusted according to BP re nitial Dose: $1 \mathrm{mg}$ at bedtime. Observe the initial dosing regimen strictly to minimize potential for severe hypoten.

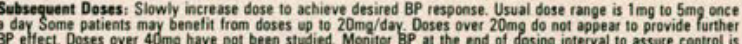
BP effect Doses over $40 \mathrm{mg}$ have not been stuvited. Monitor BP at the end of dosing interval to assure control is similar, and to evaluate symptoms which can resuit from excesssive hypotensive response. If response is substan. tially diminished at 24 hrs consider an increased dose of bid. regimen. If administration is discontinued for Use With Other Drugs: Caution should be observed when terazosin is administered concomitantly with other an-

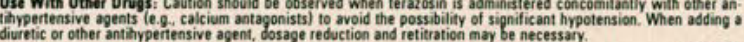
diuretic or other antihypentensive agent, dosage reduction and retitration may be necessary.
Revised: Sept. 1988 Abbott Health Care Products, Inc. North Chicago, Il 60064 References: 1. HYTRIN Product Information, Abbott Laboratories. 2. Deger G: Effect of terazosin on serum lipids. Am J Med 1986;80(supp/ 58):82-85. 3. Dzau VJ: Evolution of the clinical management of hypertension: Emerging role of "specific" vasodilators as initial therapy. Am J Med 1987;82(suppl 1A):36-43. 4. Weinberger MH: The effects of antihypertensive therapy on lipids. Cardiovasc Med 1986;11:10-11. 5. Ames RP. The effects of antihypertensive drugs on serum lipids and lipoproteins. II. Non-diuretic drugs. Drugs 1986;32:335-357. 
TABLE 7. RESIDENTS IN AOA-APPROVED NONOSTEOPATHIC PROGRAMS 1986-87 THROUGH 1988-89.

Aerospace Medicine

Anesthesiology

Cardiology

Dermatology

Emergency Medicine

Endocrinology

Gastroenterology

General Practice

Hematology

Hematology/Oncology

Infectious Disease

Internal Medicine

Maternal/Fetal Medicine

Medical Diseases of the Chest

Neonatal Medicine

Nephrology

Neurological Surgery

Neurology

Neuroradiology

Nuclear Medicine

Obstetrics and Gynecological Surgery

Occupational and Environmental

Medicine

Oncology

Ophthalmology

Orthopedic Surgery

Otolaryngology

Otorhinolaryngology

Otorhinolaryngology and

Oro-Facial Plastic Surgery

Pathology

Pediatrics

Plastic and Reconstructive Surgery

Proctology

Psychiatry

Psychiatry, Child

Public Health

Radiation Oncology

Radiology

Radiology, Diagnostic

Rehabilitation Medicine

Rheumatology

Surgery, General

Surgery, Thoracic and

Cardiovascular

Surgery, Urologic

Surgery, General Vascular

Totals

\begin{tabular}{|c|c|c|}
\hline \multicolumn{3}{|c|}{$1986-87$} \\
\hline $\mathrm{N} / \mathrm{O}^{*}$ & $\mathbf{M} \dagger$ & $\mathrm{P} \ddagger$ \\
\hline 1 & 2 & 0 \\
\hline 3 & 8 & 0 \\
\hline 4 & 0 & 0 \\
\hline 3 & 2 & 10 \\
\hline 4 & 2 & 0 \\
\hline 3 & 0 & 0 \\
\hline 1 & 1 & 0 \\
\hline 0 & 4 & 0 \\
\hline 0 & 0 & 0 \\
\hline 5 & 0 & 0 \\
\hline 4 & 0 & 0 \\
\hline 0 & 6 & 0 \\
\hline 2 & 0 & 0 \\
\hline 3 & 0 & 0 \\
\hline 0 & 0 & 0 \\
\hline 3 & 0 & 0 \\
\hline 2 & 0 & 0 \\
\hline 15 & 2 & 0 \\
\hline 1 & 0 & 0 \\
\hline 0 & 0 & 0 \\
\hline 2 & 10 & 0 \\
\hline 1 & 0 & 0 \\
\hline 4 & 0 & 0 \\
\hline 2 & 3 & 1 \\
\hline 1 & 3 & 0 \\
\hline 1 & 1 & 0 \\
\hline 0 & 0 & 0 \\
\hline 0 & 1 & 0 \\
\hline 0 & 1 & 0 \\
\hline 0 & 5 & 0 \\
\hline 2 & 1 & 0 \\
\hline 0 & 0 & 1 \\
\hline 21 & 2 & 0 \\
\hline 0 & 0 & 0 \\
\hline 3 & 0 & 0 \\
\hline 2 & 0 & 0 \\
\hline 0 & 2 & 0 \\
\hline 0 & 5 & 0 \\
\hline 13 & 0 & 0 \\
\hline 3 & 0 & 0 \\
\hline 0 & 2 & 0 \\
\hline 6 & 0 & 0 \\
\hline 1 & 1 & 0 \\
\hline 1 & 0 & 0 \\
\hline$\overline{117}$ & 64 & 12 \\
\hline
\end{tabular}

\begin{tabular}{rrr}
\multicolumn{3}{c}{$1987-88$} \\
N/O & M & P \\
\hline 2 & 2 & 0 \\
3 & 7 & 0 \\
11 & 0 & 0 \\
4 & 3 & 18 \\
7 & 3 & 0 \\
1 & 0 & 0 \\
3 & 0 & 0 \\
2 & 16 & 0 \\
1 & 0 & 0 \\
4 & 0 & 0 \\
1 & 0 & 0 \\
0 & 4 & 0 \\
1 & 0 & 0 \\
5 & 0 & 0 \\
2 & 0 & 0 \\
5 & 0 & 0 \\
2 & 0 & 0 \\
24 & 2 & 0 \\
0 & 0 & 0 \\
0 & 0 & 0 \\
2 & 5 & 0
\end{tabular}

100

$\begin{array}{lll}2 & 0 & 0 \\ 3 & 2 & 1\end{array}$

$\begin{array}{lll}0 & 2 & 1 \\ 0 & 3 & 0\end{array}$

$\begin{array}{lll}0 & 1 & 0\end{array}$

$\begin{array}{lll}0 & 0 & 0\end{array}$

$\begin{array}{lll}0 & 0 & 0 \\ 0 & 2 & 0\end{array}$

$\begin{array}{lll}0 & 2 & 0\end{array}$

$\begin{array}{lll}1 & 0 & 0 \\ 0 & 0 & 1\end{array}$

$\begin{array}{lll}21 & 3 & 0\end{array}$

$\begin{array}{lll}0 & 0 & 0\end{array}$

$\begin{array}{lll}3 & 1 & 0 \\ 3 & 0 & 0\end{array}$

$\begin{array}{lll}0 & 2 & 0\end{array}$

$\begin{array}{lll}0 & 6 & 0\end{array}$

$\begin{array}{lll}23 & 0 & 0\end{array}$

$\begin{array}{lll}4 & 0 & 0\end{array}$

300

$\begin{array}{lll}3 & 0 & 0 \\ 0 & 1 & 0 \\ 1 & 0 & 0\end{array}$

$\overline{145} \quad \overline{67} \quad \overline{20}$
1988-89

\begin{tabular}{rrr} 
N/O & M & P \\
\hline 3 & 11 & 0 \\
2 & 10 & 0 \\
12 & 0 & 0 \\
1 & 2 & 24 \\
12 & 2 & 0 \\
3 & 0 & 0 \\
3 & 0 & 0 \\
2 & 8 & 0 \\
6 & 0 & 0 \\
4 & 0 & 0 \\
3 & 0 & 0 \\
0 & 3 & 0 \\
0 & 0 & 0 \\
6 & 1 & 0 \\
3 & 0 & 0 \\
3 & 0 & 0 \\
1 & 0 & 0 \\
26 & 1 & 0 \\
5 & 0 & 0 \\
0 & 0 & 0 \\
2 & 3 & 0 \\
& &
\end{tabular}

$\begin{array}{lll}8 & 0 & 0\end{array}$

$\begin{array}{lll}3 & 0 & 0\end{array}$

$\begin{array}{lll}2 & 0 & 1\end{array}$

$\begin{array}{lll}0 & 3 & 0\end{array}$

$\begin{array}{lll}1 & 2 & 0\end{array}$

$\begin{array}{lll}0 & 1 & 0\end{array}$

$\begin{array}{lll}0 & 0 & 0\end{array}$

$\begin{array}{lll}1 & 3 & 0\end{array}$

$\begin{array}{lll}0 & 4 & 0\end{array}$

$\begin{array}{lll}8 & 0 & 3\end{array}$

$\begin{array}{lll}0 & 0 & 1\end{array}$

$\begin{array}{lll}33 & 5 & 0\end{array}$

200

$\begin{array}{lll}4 & 0 & 0\end{array}$

200

$\begin{array}{lll}0 & 1 & 0\end{array}$

$\begin{array}{rrr}0 & 4 & 0 \\ 33 & 1 & 0\end{array}$

400

$\begin{array}{lll}0 & 3 & 0\end{array}$

$\begin{array}{lll}6 & 0 & 0\end{array}$

$\begin{array}{lll}1 & 1 & 0\end{array}$

2000

$\overline{207} \overline{69} \overline{29}$

${ }^{*} \mathrm{~N} / \mathrm{O}=$ nonosteopathic residents in training.

$+\mathrm{M}=$ military residents in training.

$\ddagger \mathrm{P}=$ physicians enrolled as preceptees.

Increases in the number of osteopathic graduates has led to dramatic changes in the need for postdoctoral positions. This in turn has led to changes in expansion of AOA internships and residencies and to changes in AOA policies and procedures.

Details regarding program approval, internship and residency requirements, names of active programs, and information on certification are available on request from the AOA Department of Edu- cation, Division of Postdoctoral Training, 142 E. Ontario Street, Chicago, Illinois 60611.

Dr Ward and Dr Baker are director and associate director, respectively, of the AOA Department of Education.

Reprint requests to Dr Ward, AOA Department of Education, 142 E Ontario, Chicago 60611. 
